\title{
Peertechz
}

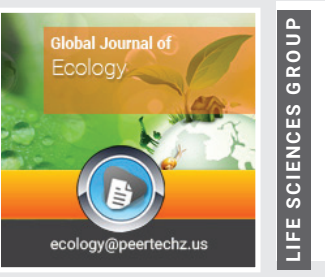

\section{Web application: Contribute to environment conservation}

\author{
Pralhad R Gavali, Vrushabh Kupwade, Mayuri Kulkarni* \\ and Sumit Vajarinkar
}

Department of CSIT, Rajarambapu Institute of Technology, Rajaramnagar, Uran Islampur, Maharashtra 415414, India
Received: 15 May, 2021

Accepted: 05 July, 2021

Published: 06 July, 2021

*Corresponding author: Mayuri Kulkarni, Department of CSIT, Rajarambapu Institute of Technology, Rajaramnagar, Uran Islampur, Maharashtra 415414, India, E-mail: mayurikulkarni25@gmail.com

https://www.peertechzpublications.com

Check for updates

\begin{abstract}
This website application will automate the major web operations. Everyone busy in their lives that they are finding convenient way to our refreshment, our comfortzone that's way there is need to contribute for the Environment Conservation. The software product to be produced is a website application which will automate the major web operations. So we create such website application which helpful to user's for contribute for the conservation.

The purpose of this paper is to contribute for the environment with efficient way that could influence online user's perceptions and their behaviors, in order to achieve a successful website application. The main motive is to all users have to be more collaborative for this website. This is open for all and everyone can use it, no one is the owner, no one is a worker, everyone is a contributor for this collaboration.
\end{abstract}

\section{Introduction}

Environment plays an important role in healthy living and the existence of life on planet Earth. Earth is a home for different living species and we all are dependent on environment for food air, water and other needs therefore it is important for every individual to save and protect our environment One man cannot change the things but the community of people can change it. From this thought, we decide to create a community for budding environment enthusiasts who want to contribute for conserving the environment. Greenies can contribute not only occasionally but also regular environment conserving activities by means of controlling pollution, donation planting trees, etc. If people take care of their area then the overall environment will be preserved. Basically in rural area there is no proper management working so, workers don't do as productive contribute for the Environment so from this website they take help and do more efficient work. Also all users have to manage our all work in at place through the communicate each other. Basically website content is in the home page users have a separate tab for profile, donate, collaborate also the information related previously held tree plantations drives, competition and other environmental related information with some eco-friendly ideas to conserve the environment.

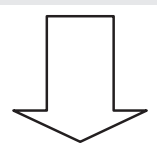

Donation

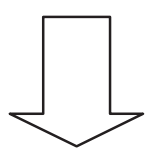

Collaboration

\section{Background}

The clear understanding of the website and its functionality will allow for the correct software to be developed the end user and will be used for the development of the future stages of the project [1-3].

The purpose is anyone who wants to contribute in a conserving environment they can use this website application and find suitable work. Environment plays an important role in healthy living and the existence of life on planet Earth. 
Earth is a home for different living species and we all are dependent on environment for food air, water and needs therefore it is important for every individual to save and protect our environment, one man cannot change the things but the community of people can change it. From this thought, we decide to create a community for budding environment enthusiasts who want to contribute for conserving the environment.

Some references to inspired it:

Title: Research Essay on the Effects of Charity Website Design on Online Donations.

The central theme of this study is that cues can assume multiple roles, serving as central or peripheral cues, depending on an elaboration state. This website basically focuses on elaboration and donation information on the basis of financial performance.

Title: Fundraising in an Interactive Online Environment.

This study investigates how nonprofit organizations could develop their website with increasing fundraising. It basically focuses on interaction between unity of celebrity with the nonprofit organization and level of interactivity include more experience about website.

\section{Methodology}

We used qualitative methods to gather the data about user's who may experience website application. This

Method included basically three stages,

- $\quad$ First stage is a sign-in and sign-up

- Payment Gateway

- Collaboration

Sign-in and Sign-up process used to keep track of members. Anyone who wants to contribute for the environment they fill all the data and create our profile. Good profile is important to know who is user and how they like to work in website effectively. If anyone wants to donate money for the purpose of conserving the environment can donate it through online payment using some features UPIs like Google Pay, Paytm, PhonePay, Paypal, etc.., debit card, rupay card, online banking. This are all Third parties application but it is secure anyone can use friendly. When we donate some amount then after successfully transaction we will get receipt in the form of text also PDF-form through mail. Collaboration section used to real time communication. Where user's can interact as well as collaborate with each other to decide and discuss where they can organize tree plantation drives, competition etc. Users need to create a chat room for this, and need to share code which others are able to join the chat room to discuss related their work, subjects. So use real time communication user's count increases to proper discussion and collaborate with unity.

\section{Primary data}

To collect all information (data) we use survey method. We find out what is the requirements of users as well as companies, and then we add new features in the web application. First of all we understand the user's problem then according to that we design our web application.
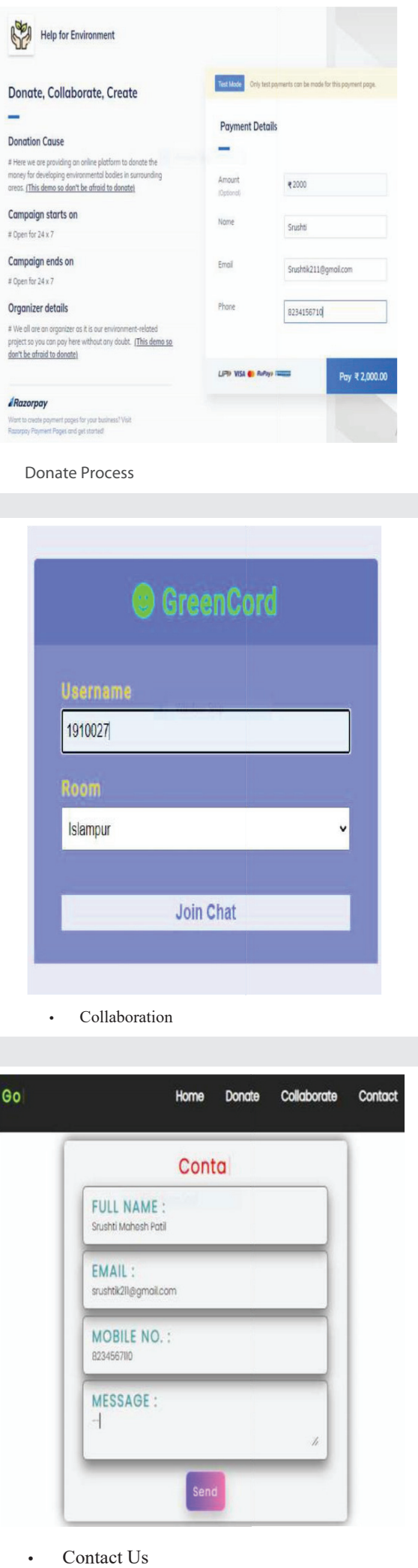

Citation: Gavali PR, Kupwade V, Kulkarni M, Vajarinkar S (2021) Web application: Contribute to environment conservation. Glob J Ecol 6(1): 062-064. 


\section{Secondary data}

We take the help of internet, newspaper, books to collect data and then we finalize our application.

From this figures we get clear idea what is exactly working of the website and which process user's can do step by step, so team used web development technologies and contribute for environment.

Donatekart charity: We are India's first 100\% transparent online donation platform for charities, where people can directly donate products needed instead of money.

Environmental defense fund: We are India's first 100\% transparent online donation platform for charities, where people can directly donate products needed instead of money.

\section{Results}

In website included three parts profile, donation, collaboration, from that we find all the contents are working good and user's show their interest to take benefit from it.

Analysis of project components, review of code and other functional requirements and amendment in existing and their summary mentioned from here:

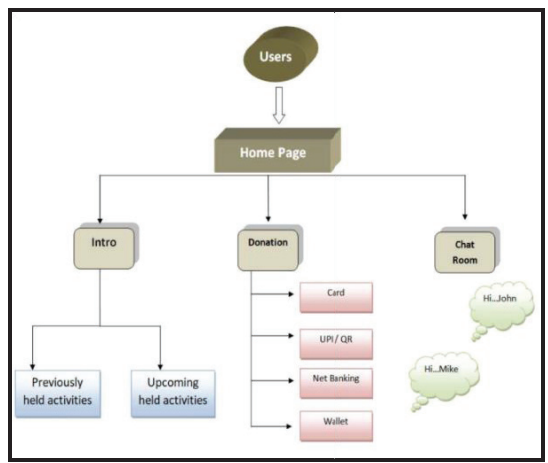

\begin{tabular}{|c|c|c|}
\hline Sr.No & Result & Accuracy \\
\hline 1. & All functionality running well & $99.00 \%$ \\
\hline 2. & Compatible with all browsers & $100 \%$ \\
\hline 3. & Useful for online mode & $90.00 \%$ \\
\hline 4. & No bugs found during test phases & $99.00 \%$ \\
\hline 5. & Flow of content of nonpersistent during some & \\
\hline & circumstances (Persistency: & $90.00 \%$ \\
\hline
\end{tabular}

$0.90)$

\section{Conclusion}

Increasing more number of contribution in the development of environment.

This web application helps to increasing employers. In some companies they find employees to do work faster, so this application easily helps to find employees to do work as efficiently.

To create good reputation in being environmentally friendly, supporting user's and providing positive working conditions. Ultimate the motive is to conserve the environment. We can further develop this web application into mobile apps using some changes and also can add further features to make it more interactive and user friendly

Basically This website application is eco-friendly so, user's easily work with website and user's as well as companies satisfies there requirement.

\section{References}

1. Patil S, Patil N, Bhatambrekar S, Kulkarni S (2008) Android App: Personal Finance(Pf). Link: https://bit.ly/3hjsKTr

2. (2012) Microcontroller based fault detector. International Journal of Advancements in research and Technology 1. Link: https://bit.ly/3hCS9pP

3. Chemical Engineering research and Design. 89: 836.
Discover a bigger Impact and Visibility of your article publication with

Peertechz Publications

Highlights

* Signatory publisher of ORCID

* Signatory Publisher of DORA (San Francisco Declaration on Research Assessment)

* Articles archived in worlds' renowned service providers such as Portico, CNKI, AGRIS, TDNet, Base (Bielefeld University Library), CrossRef, Scilit, J-Gate etc.

* Journals indexed in ICMJE, SHERPA/ROMEO, Google Scholar etc.

* OAI-PMH (Open Archives Initiative Protocol for Metadata Harvesting)

* Dedicated Editorial Board for every journal

* Accurate and rapid peer-review process

* Increased citations of published articles through promotions

* Reduced timeline for article publication

Submit your articles and experience a new surge in publication services (https://www.peertechz.com/submission).

Peertechz journals wishes everlasting success in your every endeavours.

Copyright: (C) 2021 Gavali PR, et al. This is an open-access article distributed under the terms of the Creative Commons Attribution License, which permits unrestricted use, distribution, and reproduction in any medium, provided the original author and source are credited. 